\title{
UJI EFEKTIVITAS ANTI MIKROBA EKSTRAK DAUN KERSEN (Muntingia calabura Linn)TERHADAP BAKTERI Salmonella sp.
}

\author{
${ }^{1}$ Miftachul Sobirin \\ ${ }^{1}$ STIKes Borneo Cendekia Medika Pangkalan Bun \\ ${ }^{1}$ Email : miftachul_sob@yahoo.co.id
}

\begin{abstract}
ABSTRAK
Salmonella typhi merupakan bakteri penyebab salmonellosis yang merupakan salah satu penyakit edemis dan menimbulkan kerugian yang serius terutama di Negara berkembang termasuk Indonesia. Bakteri Salmonella ditularkan melalui makanan dan minuman yang terkontaminasi kotoran atau tinja dari seorang penderita tifoid. Semakin banyak penggunaan antibiotik dapat menyebabkan resistensi bakteri, sehingga diperlukan adanya penelitian tentang antibiotik dari bahan alami salah satunya menggunakan daun Kersen (Muntingia calabura L ). Penelitian ini bertujuan untuk mengetahui zona hambat daun $M$. calabura terhadap bakteri $S$. typhi. Uji aktivitas antibakteri ekstrak etil asetat daun $M$. calabura terhadap bakteri S. typhi menggunakan metode difusi agar Kirby Bauer. Zona hambat yang terbentuk diidentifikasi dengan melihat daerah bening disekeliling cakram dan besarnya zona hambat diketahui berdasarkan pengukuran diameter daerah bening tersebut. Zona bening yang terbentuk pada konsentrasi $1000 \mathrm{ppm}=11 \mathrm{~mm}, 500 \mathrm{ppm}=9 \mathrm{~mm}, 250$ $\mathrm{ppm}=9 \mathrm{~mm}$ dan $125 \mathrm{ppm}=0 \mathrm{~mm}$. Semakin besar konsentrasi ekstrak, semakin besar pula zona hambat yang terbentuk. Ekstrak dengan konsentrasi yang tinggi mengandung senyawa aktif dengan kadar yang tinggi, sehingga lebih besar daya hambatnya.
\end{abstract}

Kata Kunci : Salmonella typhi, Muntingia calabura, antibakteri

THE EFFECTIVENESS TEST OF ANTI-MICROBIAL EXTRACT OF KERSEN LEAF (Muntingia calabura Linn) ON BACTERIA Salmonella sp.

\footnotetext{
ABSTRACT

Salmonella typhi is a bacterium that causes salmonellosis which is an edemic disease and causes serious losses, especially in developing countries including Indonesia. Salmonella bacteria are transmitted through food and drink contaminated with feces or feces from a typhoid sufferer. The more use of antibiotics can cause bacterial
} 
resistance, so research is needed on antibiotics from natural ingredients, one of which uses leaves Kersen (Muntingia calabura L). This study aims to determine the inhibitory zone of M. calabura leaves against S. typhi bacteria. The antibacterial activity test of ethyl acetate extract of $M$. calabura leaves against $S$. typhi bacteria using Kirby Bauer agar diffusion method. The inhibition zone that is formed is identified by looking at the clear area around the disc and the amount of the inhibition zone is known based on the measurement of the diameter of the clear area. Clear zones formed at concentrations of $1000 \mathrm{ppm}=11 \mathrm{~mm}, 500 \mathrm{ppm}=9 \mathrm{~mm}, 250 \mathrm{ppm}=9 \mathrm{~mm}$ and $125 \mathrm{ppm}=0 \mathrm{~mm}$. The greater the concentration of the extract, the greater the inhibitory zone formed. Extracts with high concentrations contain active compounds with high levels, so greater inhibitory power.

Keywords: Salmonella typhi, Muntingia calabura, antibacterial

\section{PENDAHULUAN}

Salmonella typhi merupakan bakteri penyebab salmonellosis yang merupakan salah satu penyakit edemis dan menimbulkan kerugian yang serius terutama di Negara berkembang termasuk Indonesia. Bakteri Salmonella ditularkan melalui makanan dan minuman yang terkontaminasi kotoran atau tinja dari seorang penderita tifoid. Bakteri masuk melalui mulut bersama makanan dan minuman, kemudian berlanjut kesaluran pencernaan. Jika bakteri yang masuk dengan jumlah yang banyak maka bakteri akan masuk ke dalam usus halus selanjutnya masuk ke dalam sistem peredaran darah sehingga menyebabkan bakterimia, demam tifoid dan komplikasi organ lain (Wagner, 2014).

S. typhi adalah bakteri penyebab demam tifoid. Penyakit ini menyerang hampir disemua negara, terutama di negara - negara berkembang seperti Indonesia. Angka kejadian demam tifoid tergantung dari banyak hal diantaranya kebersihan lingkungan dan perilaku masyarakat. Di Indonesia angka kejadian demam tifoid sebesar $1,5 \%$ yang artinya terdapat kasus demam tifoid 1.500/100.000 penduduk Indonesia (Herawati dan Ghani, 2009). Pada tahun 2017 mengalami peningkatan sebanyak 235 kasus demam tifoid. 
Pada bulan januari 2018 kasus demam tifoid sebanyak 7 kasus (Rumah Sakit Abunawas, 2018).

Pengobatan penyakit yang disebabkan bakterimenggunakan antibiotik sudah banyak dilakukan, sehingga menyebabkan resistansi pada bakteri. Oleh sebab itu perlu dilakukan penelitian menggunakan bahan alami salah satunya adalah menggunakan daun kersen (Muntingia calaburaLinn). $M$. calabura Beberapa penelitian mengungkapkan bahwa daun kersen mengandung flavonoid, saponin, tanin, dan polifenol yang bersifat antibakteri (Surjowardojo, dkk, 2014). Senyawa-senyawa tersebut dapat digunakan sebagai antibakteri.

Berdasarkan latar belakang di atas maka dilakukan penelitian tentang ekstrak daun $M$. calabura terhadap S. typhi. Penelitian ini menggunakan metode difusi kertas cakram, dimana daerah zona hambat yang terbentuk dapat terukur sehingga dapat diketahui efektivitas ekstrak M. calabura terhadap $S$. typhi.

\section{METODE PENELITIAN}

Alat
Alat yang digunakan dalam penelitian yaitu: autoklaf, Laminar air flow, rotary evaporatory (Stuart), hot plate (Stuart), gunting, ember, nampan aluminium, blender, saringan ukuran 60 mesh, beaker glass $1000 \mathrm{ml}$, timbangan analitik, labu Erlenmeyer, spidol, buku tulis, tabung reaksi, rak tabung reaksi, pipet ukur, pipet tetes, vortex, stirrer, gelas ukur, karet gelang, lampu bunsen, korek api, masker, handstool, ose bulat, oven, petri dish, mikropipet, yellow tip, drugalsky, kertas cakram $6 \mathrm{~mm}$, kamera, penggaris, panci.

\section{Bahan}

Bahan yang digunakan dalam penelitian meliputi:

a. Pembuatan ekstrak

etil asetat, aquades, kertas saring, Sulfoxide dimetil (DMSO) $5 \%$, aluminium foil, wrapping, kertas label dan kertas tisu.

b. Uji antimikroba

Bubuk Nutrient Agar (NA), bubuk Nutrient Broth (NB), biakan bakteri $S$. typhi

\section{Rancangan Penelitian}

Penelitian ini menggunakan metode eksperimental dengan perlakuan uji daya hambat menggunakan ekstrak etil asetat 
konsentrasi 1000, 500, 2500, 1250 ppm terhadap, dengan 4 kali ulangan,

\section{Variabel penelitian}

Variabel yang digunakan adalah variabel bebas dan variabel tergantung. Variabel bebas pada penentuan pelarut terbaik adalah jenis pelarut, sedangkan variabel tergantungnya adalah daya antimikroba dari ekstrak etil asetat

\section{Cara Kerja}

\section{Persiapan dan pembuatan} simplisia (Fadhilah et al., 2014) dengan modifikasi

Keseluruhan daun M. calabura dipetik menggunakan gunting lalu diseleksi daun yang terbaik. Daun dengan air mengalir dengan waktu yang sesingkat mungkin bertujuan untuk menghilangkan pengotor, namun tidak menghilangkan zat berkhasiat simplisia tersebut. Daun ditiriskan dan dipotong kecil-kecil \pm $3 \mathrm{~cm}$, selanjutnya simplisia dikering anginkan selama 5 hari, lalu dikeringkan menggunakan oven pada suhu $50^{\circ} \mathrm{C}$ selama 2 hari. Setelah umbi kering daun dihancurkan menggunakan blender kemudian disaring dengan penyaring ukuran 60 mesh.
2 Ekstraksi (Moningka et al., 2015)

$$
\begin{aligned}
& \text { Ekstraksi dilakukan } \\
& \text { menggunakan metode maserasi }
\end{aligned}
$$

\section{Uji aktivitas antibakteri}

a. Pembuatan larutan uji

Dibuat larutan ekstrak 1000 ppm dengan cara 
melarutkan 0,002 gram ekstrak dalam $2 \mathrm{ml}$ DMSO 5\%

b. Pembuatan larutan stok untuk uji variasi konsentrasi

Larutan ekstrak dengan konsentrasi 1000 ppm dibuat dengan melarutkan 0,020 gram ekstrak dalam $20 \mathrm{ml}$ DMSO 5\%

c. Pembuatan variasi konsentrasi (Chang, 2004)

Larutan stok antibakteri dan antifungi yang tersedia dibuat seri konsentrasi didasarkan metode pengenceran menggunakan rumus sebagai berikut:

$$
\mathbf{V}_{1} \mathbf{N}_{1}=\mathbf{V}_{2} \mathbf{N}_{2}
$$

\section{Keterangan:}

$\mathrm{V}_{1}=$ volume larutan stok

$\mathrm{N}_{1}=$ konsentrasi larutan stok yang tersedia (1000 ppm)

$\mathrm{V}_{2}=$ volume larutan yang akan dibuat (2 $\mathrm{ml})$

$\mathrm{N}_{2}=$ konsentrasi larutan yang akan dibuat

d. Pembuatan Medium NA

(Prawira et al., 2013)

Pembuatan media NA yaitu dengan melarutkan 2,8 gr bubuk NA dengan $100 \mathrm{ml}$ aquades ke dalam beaker glass dan ditutup alumunium foil, distirer dengan pemanas hingga mendidih kemudian media NA dimasukkan ke labu Erlenmeyer, kemudian disteril dengan autoklaf pada suhu $121^{\circ} \mathrm{C}$ selama 15 menit dan tekanan 1 atm.

e. Pembuatan Medium NB (Prawira et al., 2013)

Pembuatan media NB yaitu dengan melarutkan 1,3 gr bubuk NB dengan $100 \mathrm{ml}$ aquadest kedalam beaker glass dan ditutup alumunium foil, distirer dengan pemanas hingga mendidih lalu dimasukkan ke tabung reaksi masing-masing 10 ml, kemudian ditutup dengan kapas dan alumunium foil lalu disteril dengan autoklaf pada suhu $121^{\circ} \mathrm{C}$ selama 15 menit dan tekanan $1 \mathrm{~atm}$.

f.Peremajaan isolat mikroba uji (Efendi dan Hertiani, 2013)

Sebanyak satu ose dari kultur bakteri digoreskan pada media NA miring dan diinkubasi $35^{\circ} \mathrm{C}-37^{\circ} \mathrm{C}$ selama $18-24$ jam, kemudian diambil satu ose dari hasil subkultur bakteri tersebut, disuspensikan dalam $10 \mathrm{ml}$ media cair NB, diinkubasi selama 18-24 jam pada suhu $35^{\circ} \mathrm{C}-37^{\circ} \mathrm{C}$. 
g. Uji aktivitas antibakteri berbagai pelarut (Efendi dan Hertiani, 2013)

Sebanyak $10 \mathrm{ml}$ media NA untuk dimasukkan ke dalam cawan petri kemudian dimasukkan $100 \mu \mathrm{L}$ mikroba, mikroba tersebut diratakan dengan drugalsky. Diteteskan ekstrak etil asetat sebanyak $50 \mu 1$ dengan konsentrasi 1000 ppm pada masing-masing kertas cakram, kemudian kertas cakram tersebut diletakkan di atas media agar. Setelah didiamkan selama 30 menit, cawan diinkubasi pada suhu $37^{\circ} \mathrm{C}$ selama $16-18$ jam. Adanya daerah bening di sekeliling cakram kertas menunjukkan adanya aktivitas antibakteri. Zona bening tersebut diukur diameternya menggunakan penggaris.

\section{Analisis Data}

Data yang diperoleh selanjutnya dianalisis secara deskriptif kuantitatif

\section{HASIL DAN PEMBAHASAN Ekstraksi}

Daun M. calabura yang diambil di Pangkalan Bun sampel dikumpulkan sebanyak $3 \mathrm{~kg}$ kemudian dibersihkan dengan menggunakan air mengalir bersih kemudian dikeringkan dengan cara diangin-anginkan. Pengeringan bertujuan untuk menurunkan aktivitas kadar air dalam bahan sehingga mikroorganisme penyebab kerusakan bahan tidak dapat hidup dan dapat disimpan dalam jangka waktu yang lebih lama. Simplisia yang telah kering diserbukkan dengan menggunakan blender, kemudian diayak dengan menggunakan ayakan mesh 60 hingga diperoleh serbuk yang halus. Pembuatan serbuk bertujuan untuk memperluas permukaan yang berinteraksi dengan pelarut sehingga lebih banyak senyawa yang dapat terekstrak.

Metode yang digunakan dalam pembuatan ekstrak daun $M$. calabura dilakukan dengan metode maserasi. Metode maserasi ini mempunyai beberapa kelebihan diantaranya cara pengerjaan dan peralatan yang digunakan sederhana dan tidak merusak senyawa yang tidak tahan panas. Pelarut untuk ekstraksi mempunyai kepolaran yang sama dengan senyawa yang akan diambil. Hal ini disebabkan kandungan kimia dari suatu tumbuhan hanya dapat larut dalam pelarut yang sama kepolarannya. Pemilihan pelarut 
ekstraksi didasarkan pada prinsip like dissolved like yaitu senyawa polar akan cenderung larut pada pelarut polar dan senyawa non polar akan cenderung larut pada pelarut non polar, sehingga $n$ heksana akan melarutkan senyawa non polar, etil asetat akan melarutkan senyawa semi polar,

Simplisia Daun M. calabura diekstraksi menggunakan masingmasing pelarut selama 5 hari, dan dilakukan pengulangan dengan penggantian pelarut selama 2 hari, bertujuan untuk mengekstrak seluruh senyawa kimia yang ada dalam sampel (Moningka, 2015). Selanjutnya hasil rendaman dilakukan pemisahan yang terdiri dari penyaringan dan evaporasi. Penyaringan dilakukan untuk memisahkan sampel dengan pelarut yang telah mengandung bahan aktif. Pemisahan pelarut dengan senyawa bioaktif yang terikat dilakukan evaporasi menggunakan rotary evaporator. Sehingga didapatkan ekstrak kental bebas pelarut yang siap digunakan untuk uji antibakteri terhadap $S$. typhi. Ekstrak yang digunakan dalam uji antibakteri pada penelitian ini adalah ekstrak etil asetat

\section{M. calabura}

\section{Uji Aktivitas Antibakteri}

Uji aktivitas antibakteri ekstrak etil asetat daun $M$. calabura terhadap bakteri S. typhi menggunakan metode difusi agar Kirby Bauer. Pengujian menggunakan kertas cakram berdiameter $6 \mathrm{~mm}$ yang telah disterilkan terlebih dahulu dan setiap kertas cakram diresapi sebanyak $50 \quad \mu \mathrm{L}$ larutan uji/ekstrak dengan berbagai pelarut konsentrasi 1000, 500, 250, 125 ppm. Zona hambat yang terbentuk diidentifikasi dengan melihat daerah bening disekeliling cakram dan besarnya zona hambat diketahui berdasarkan pengukuran diameter daerah bening tersebut.

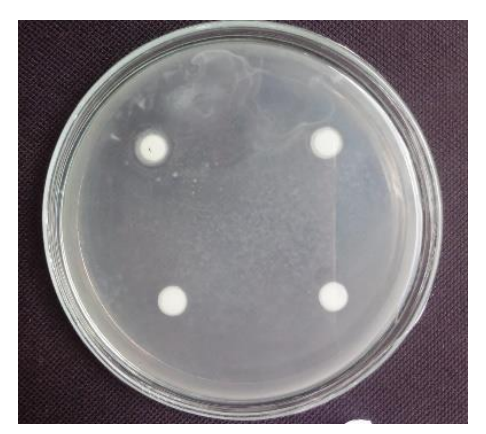

Gambar 4.1 Zona hambat ujiantibakteri daun M. calabura terhadap S. typhi

Rata-rata hasil pengukuran diameter zona hambat daun M. calabura terhadap S. typhi dapat dilihat pada diagram batang 4.2 


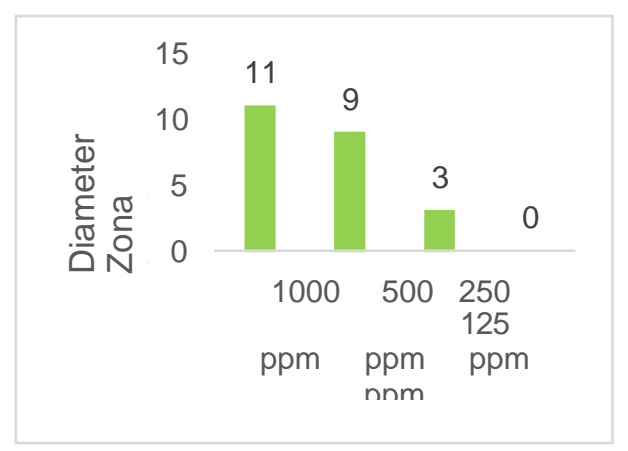

Gambar 4.2 Konsentrasi ekstrak daun $M$. calabura terhadap S. typhi

Ekstrak etil asetat membentuk zona hambat karena etil asetat mengandung senyawa antimikroba yang mampu menghambat atau membunuh mikroba lebih tinggi dibandingkan ekstrak yang lainnya. Fitrial et al. (2008) menyatakan senyawa semipolar mempunyai afinitas lebih tinggi untuk berinteraksi dengan diding sel, sehingga ekstrak semipolar lebih efektif menghambat pertumbuhan bakteri.

Hasil uji menunjukkan semakin besar konsentrasi ekstrak, semakin besar pula zona hambat yang terbentuk. Ekstrak dengan konsentrasi yang tinggi mengandung senyawa aktif dengan kadar yang tinggi, sehingga lebih besar daya hambatnya. Pada konsentrasi 250 ppm masih terbentuk zona hambat sedangkan pada konsentrasi 12.5 ppm tidak ada zona hambat yang terbentuk, sehingga konsentrasi terendah yang mampu menghambat mikroba uji adalah 250 ppm. Menurut Nurmahani et al. (2012) dalam Rakasiwi dan Soegiharjo (2014), KHM didefinisikan sebagai konsentrasi terendah ekstrak yang dapat menghambat pertumbuhan bakteri dalam waktu 24 jam inkubasi.

\section{KESIMPULAN}

Berdasarkan penelitian dapat disimpulkan bahwa:

Ekstrak etil asetat berpengaruh terhadap zona hambat bakteri ditandai dengan adanya zona hambat pada perlakuan

\section{DAFTAR PUSTAKA}

Badan POM, 2005. Info POM: Standarisasi Ekstrak Tumbuhan Obat Indonesia, Salah satu Tahapan Penting Dalam Pengembangan Obat Asli Indonesia. Direkotat Obat Asli Indonesia, Jakarta. . 2010. Acuan Sediaan Herbal. Direkotat Obat Asli Indonesia, Jakarta

Fadhilah, H., H. Rivai dan R. Yuandina. 2014. Pembuatan dan Karakterisasi Ekstrak Kering Daun Jambu Mete (Anacardium occidentale L.). Prosiding Seminar Nasional dan Workshop "Perkembangan Terkini Sains Farmasi dan Klinik IV", Padang. 
Fitrial, Y., M. Astawan, S. S. Soekarto, K. G. Wiryawan, T. Wresdiyati dan R. Khairina. 2008. Antibakteri Ekstrak Biji Teratai (Nymphaea pubescens Wild) terhadap Bakteri Patogen Penyebab Diare. Jurnal Teknologi dan Industri Pangan. 19 (2): 158-164.

Iskamto, B. 2009. Bakteriologi Kesehatan. UNS Press, Surakarta.

Moningka, K. C., N. S. Kojong dan S. Sudewi. 2015. Uji Aktivitas Antibakteri Ekstrak Daun Ekor Kucing (Acalypha hispida Burm. F.) terhadap Bakteri Staphylococcus aureus dan Escherichia coli secara InVitro. 4 (3): 193-202.

Ningsih, M. L. dan Warsidi. 2013. Aplikasi Hormon Tumbuh Pada Perbanyakan Tanaman Begonia Melalui Setek Daun dan Setek Irisan Daun. Balai Penelitian Teknologi Pembenihan, Balikpapan.

Prawira, M. Y., Sarwiyono dan P. Surjowardojo. 2013. Daya Hambat Dekok Daun Kersen (Muntingia calabura L.) terhadap Pertumbuhan Bakteri Staphylococcus aureus Penyebab Penyakit Mastitis pada Sapi Perah. Universitas Brawijaya, Malang.
Purwanti, L., A. Maharani dan L. Syafnir. 2014. Uji Aktivitas Antibakteri dan Isolasi Alkaloid dalam Daun Tomat (Lycopersicon esculentum Mill.). Prosiding Seminar Nasional Penelitian dan PKM Sains, Teknologi dan Kesehatan, Unisba.

Rahminiwati, M., I. Juwita, A. Murtisari dan L. K. Darusman. 2011. Aktivitas Ekstrak Temulawak (Curcuma Xanthorrhiza Roxb.) terhadap Proliferasi dan Diferensiasi Sel Otak Besar Anak Tikus Berumur Tiga Hari secara In Vitro. Fitofarmaka. 1 (2): $1-8$.

Supranto, J. 2000. Statistik Teori dan Aplikasi. Jilid 1 Edisi 6. Erlangga, Jakarta.

Susanti, A. D., D. Ardiana, G. P. Gumelar dan Y. Bening. 2012. Polaritas Pelarut sebagai Pertimbangan dalam Pemilihan Pelarut untuk Ekstraksi Minyak Bekatul dari Bekatul Varietas Ketan (Oriza sativa glatinosa). Simposium Nasional RAPI XI FT UMS, Surakarta.

Utami, P. 2012. Antibiotik Alami untuk Mengatasi Aneka Penyakit. AfroMedia Pustaka, Jakarta.

Waluyo, L. 2005. Mikrobiologi Lingkungan. UMM Press, Malang. 